\title{
Leucocyte migration studies in Crohn's disease using Crohn's colon homogenate and mitochondrial and microsomal fractions
}

\author{
ELIZABETH R. RICHENS, M. J. WILLIAMS, K. R. GOUGH, AND \\ R. J. ANCILL
}

From the Royal United Hospital, Bath

SUMMARY Leucocytes from 38 patients with Crohn's disease were tested for evidence of migration inhibition in the presence of preparations of colon from a patient with this disease. The occurrence of migration inhibition showed a positive correlation with clinically active disease and a negative correlation with immunosuppressive treatment. It was not seen with leucocytes from 12 healthy subjects.

Impairment of cellular immunity has been described in Crohn's disease (Phear, 1958; Parent, Barrett, and Dodd Wilson, 1971; Guillou, Brennan, and Giles, 1973). This state of relative anergy, with the further resemblance to sarcoidosis of a similar non-caseating granulomatous lesion seen in both conditions, has led to investigation of cellular hypersensitivity to sarcoid spleen preparations in Crohn's disease (Willoughby and Mitchell, 1971; Richens, Gough, and Williams, 1973). These studies, using the leucocyte migration technique, showed evidence of hypersensitivity to sarcoid spleen in a proportion of the Crohn's patients. The technique had previously shown no evidence of hypersensitivity to extracts of foetal colonic and jejunal mucosa in Crohn's disease, although leucocytes from a majority of patients with ulcerative colitis had shown inhibited migration to these extracts (Bendixen, 1969).

In this study we have investigated leucocyte migration in cases of Crohn's disease, using extracts from the colon of a patient with this disease. In addition to testing leucocyte migration against colon homogenate, it seemed useful to attempt to localize a possible subcellular site of hypersensitivity by testing against mitochondrial and microsomal fractions of colonic mucosa.

\section{Patients and Methods}

PATIENTS

Thirty-eight patients with Crohn's disease were

Received for publication 26 October 1973. studied: 14 males and 23 females with a mean age of 41 years. The diagnosis was established on clinical and radiological grounds alone in 21 cases and was confirmed by histological evidence in the other 17 patients who had undergone surgery. Twenty-eight patients were judged to have active disease on clinical criteria of continuing abdominal pain, weight loss, diarrhoea, anaemia, and fever, whereas the remaining 10 had none of these features and appeared well. This arbitrary classification cannot be an accurate assessment, but it was felt that an attempt should be made to correlate clinical activity of disease with the results of immunological testing.

\section{CONTROLS}

This group comprised 12 healthy subjects, six male, and six female, with a mean age of 32 years.

\section{PREPARATION OF ANTIGENS}

Under sterile conditions mucosal and submucosal layers were stripped from the muscular wall of colon removed at operation from a patient with Crohn's disease. After these had been cut into small pieces and suspended in 10 times their volume of $0.25 \mathrm{M}$ sucrose solution pH 7.2 at $4^{\circ} \mathrm{C}$, they were homogenized by 10 passes in a Potter Elvehjelm homogeniser. The homogenate was centrifuged at $600 \mathrm{~g}$ for 10 minutes, and part of the supernatant fraction retained to serve as the colonic homogenate in this study. The remainder was centrifuged at $5000 \mathrm{~g}$ for 20 minutes. The precipitate from this centrifugation was resuspended and used as the mitochondrial fraction, after two washings in $0.25 \mathrm{M}$ 
sucrose, while the supernatant was again centrifuged at $104000 \mathrm{~g}$ for one hour. The precipitate from this fraction contained the microsomes which were again resuspended. The particulate subcellular fractions were examined by negative staining in an electron microscope. Each fraction was standardized for protein content and adjusted to a concentration of $100 \mu \mathrm{g} / \mathrm{ml}$ for the final culture fluid (Lowry, Rosebrough, Farr, and Randall, 1951). All the fractions were stored in aliquots at $-20^{\circ} \mathrm{C}$.

\section{LEUCOCYTE MIGRATION TEST}

The method of Bendixen and Soborg (1969) was used with minor modifications. The theoretical basis of this test depends on the fact that lymphocytes from a sensitized individual, on contact with the specific antigen, produce a soluble migration inhibition factor (MIF) which modifies leucocyte migration. Testing leucocytes in vitro against an antigen to which the individual is hypersensitive usually results in inhibition of leucocyte migration, whereas in the absence of antigen cell migration is unaffected. Stimulation of leucocyte migration has been noted to indicate a weak hypersensitivity to the antigen used (Søborg, 1967). The method used was as follows.

Twenty-five $\mathrm{ml}$ of venous blood was collected and heparinized (Evans preservative-free heparin, 20 units $/ \mathrm{ml}$ ) and the blood allowed to sediment at $37^{\circ} \mathrm{C}$ for 45 minutes. The leucocyte-rich plasma was removed, centrifuged at $150 \mathrm{~g}$ for 10 minutes, and the cell pellet washed a further three times with phosphate-buffered saline, $\mathrm{pH} 7 \cdot 2$. The washed cells were then resuspended in Eagles MEM, supplemented with $15 \%$ foetal calf serum (Flow Laboratories), penicillin 100 units $/ \mathrm{ml}$, and streptomycin $100 \mu \mathrm{g} / \mathrm{ml}$ to a concentration of $7 \times 10^{7} \mathrm{cells} / \mathrm{ml}$. Capillary tubes (Drummond $25 \mu \mathrm{l}$ microcaps) were filled with the cell suspensions, sealed at one end (Cristaseal, Hawksley) and centrifuged at $150 \mathrm{~g}$ for five minutes. The tubes were cut $1 \mathrm{~mm}$ below the cell-fluid inter-
HOMOGENATE

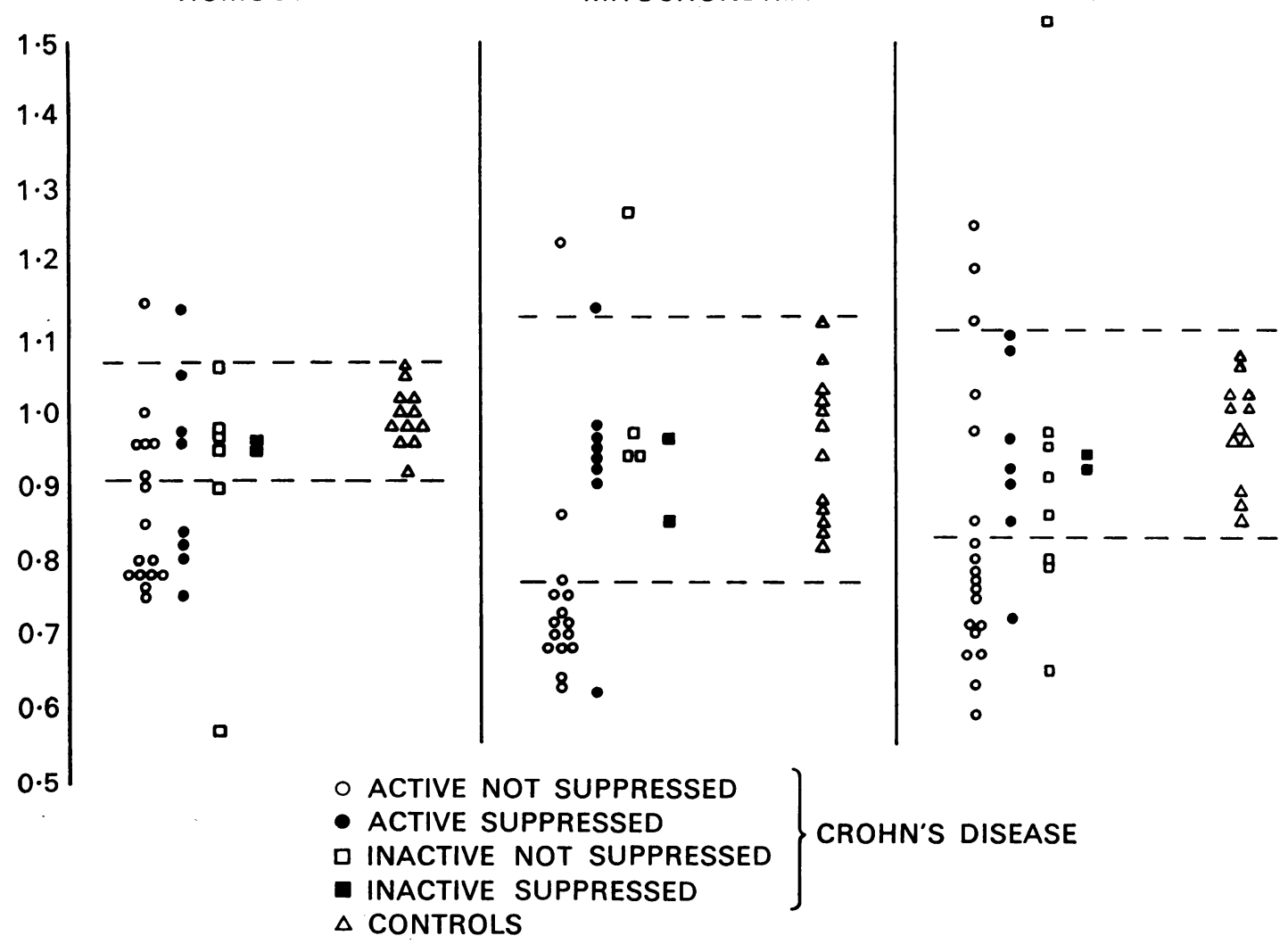

Fig Leucocyte migration indices obtained with Crohn's diseased gut constituents in various categories of Crohn's patients and normal subjects. (Dotted lines indicate range (mean $\pm 2 S D$ ) of migration indices from normal subjects.) 
space and the cell pellet was positioned by means of silicone grease in a leucocyte migration chamber (Sterilin Ltd). One series of at least three chambers was filled with culture medium alone, and a second series with culture medium plus antigen. The chambers were sealed with glass coverslips and incubated horizontally at $37^{\circ} \mathrm{C}$ for 21 hours. The migration pattern was then projected, drawn, and measured by planimetry.

The effect of antigen on cell migration was expressed as migration index (MI) as follows:

Mean migration in presence of antigen

Mean migration in absence of antigen

Results were analysed statistically using the Mann-Whitney two-sample ranking test to see if the presence of antigen had a significant effect on cell migration. The average variation between replicate cultures was $10 \%$.

\section{Results}

The effect of crude colonic mucosal homogenate on leucocyte migration is shown in the figure. The control population gave a mean $\mathrm{MI}$ of 0.99 with a range (mean \pm 2 SD) of $0.91 \rightarrow 1.07$. Eighteen of 32 Crohn's patients tested (57\%) gave abnormal migration values, ie, values outside this range; two patients $(6 \%)$ showed migration stimulation $(1.15 \pm 0.01) ; 16$
$(50 \%)$ showed inhibition $(0.79 \pm 0.10)$, and the remaining $14(44 \%)$ gave values within the normal range $(0.98 \pm 0.04)$. The difference between the two groups, total patients and controls, is significant $(P<0.005)$.

The effect of colon mitochondrial fraction on leucocyte migration is also shown in the figure. The mean migration index for the control group is 0.95 with a range of $0 \cdot 77 \rightarrow 1 \cdot 13$. Seventeen out of 29 Crohn's patients $(58 \%)$ gave abnormal migration values: three $(9 \%)$ showed stimulation $(1.21 \pm$ $0.01) ; 14$ (49\%) showed inhibition (0.70 \pm 0.07$)$; and the remaining $12(42 \%)$ gave values within the normal range $(0.93 \pm 0.03)$. The difference between the patient and control groups is again significant $(P<0.005)$.

The third section of the figure shows the effect of colon microsomalfraction onleucocytemigration. The mean migration index for the control group is 0.97 with a range of $0.83 \rightarrow 1 \cdot 11$. Twenty-two out of 36 in the Crohn's group (61\%) gave abnormal migration values: four patients $(11 \%)$ showed stimulation $(1.27 \pm 0.17) ; 18(50 \%)$ showed inhibition $(0.72 \pm$ $0.03)$; and the remaining $14(39 \%)$ gave values within the normal range $(0.95 \pm 0 \cdot 10)$. The difference between the patient and control groups was again significant $(P<0.005)$.

Table I shows that with each antigen tested significant alteration of migration was shown only

\begin{tabular}{|c|c|c|c|c|c|c|}
\hline \multirow[t]{2}{*}{ Patient Group } & \multicolumn{2}{|l|}{ Homogenate } & \multicolumn{2}{|l|}{ Mitochondria } & \multicolumn{2}{|l|}{ Microsomes } \\
\hline & $M e a n \pm S D$ & $p$ & Mean $\pm S D$ & $p$ & $M e a n \pm S D$ & $p$ \\
\hline Active phase of disease, & $0.83 \pm 0.11(16)$ & $<0.005$ & $0.75 \pm 0.14(15)$ & $<0.005$ & $0.83 \pm 0.19(19)$ & $<0.005$ \\
\hline Not affected & $0.96 \pm 0.01$ & & $0.86 \pm 0.00$ & & $0.95 \pm 0.10$ & \\
\hline Stimulated & $1.15 \pm 0.00$ & & $1.23 \pm 0.00$ & & $1.19 \pm 0.10$ & \\
\hline $\begin{array}{l}\text { Inhibited } \\
\% \text { Abnormal }\end{array}$ & $\begin{array}{l}0.76 \pm 0.04(10) \\
69\end{array}$ & & $\begin{array}{l}0.70 \pm 0.06(13) \\
93\end{array}$ & & $\begin{array}{l}0.72 \pm 0.01(13) \\
84\end{array}$ & \\
\hline $\begin{array}{l}\text { Active phase of disease, } \\
\text { immunosuppressed }\end{array}$ & $0.92 \pm 0.13$ & $>0.05$ & $0.93 \pm 0.14$ & $>0.05$ & $0.93 \pm 0.13$ & $>0.05$ \\
\hline $\begin{array}{l}\text { Not affected } \\
\text { Stimulated }\end{array}$ & $\begin{array}{l}0.99 \pm 0.01 \\
1.14 \pm 0.00\end{array}$ & & $\begin{array}{l}0.94 \pm 0.07 \quad(6) \\
1.14 \pm 0.00\end{array}$ & & $0.82 \pm 0.14$ & \\
\hline $\begin{array}{l}\text { Inhibited } \\
\% \text { Abnormal }\end{array}$ & $0.80 \pm 0.04$ & & $0.62 \pm 0.00$ & & $0.98 \pm 0.14$ & \\
\hline $\begin{array}{l}\text { Inactive phase of disease, } \\
\text { no immunosuppression }\end{array}$ & $0.91 \pm 0.17$ & $>0.05$ & $1.03 \pm 0.16$ & $>0.05$ & $0.93 \pm 0.26$ & $>0.05$ \\
\hline $\begin{array}{l}\text { Not affected } \\
\text { Stimulated }\end{array}$ & $0.99 \pm 0.01$ & & $\begin{array}{l}0.95 \pm 0.01 \\
1.27 \pm 0.00\end{array}$ & & $\begin{array}{l}0.91 \pm 0.01 \\
1.52 \pm 0.00 \text { (1) }\end{array}$ & \\
\hline $\begin{array}{l}\text { Inhibited } \\
\% \text { Abnormal }\end{array}$ & $0.74 \pm 0.01$ & & & & $0.75 \pm 0.10$ & \\
\hline $\begin{array}{l}\text { Inactive phase of disease } \\
\text { immunosuppressed }\end{array}$ & $0.96 \pm 0.01$ & $>0.05$ & $0.91 \pm 0.08$ & $>0.05$ & $0.93 \pm 0.01$ & $>0.05$ \\
\hline $\begin{array}{l}\text { Not affected } \\
\text { Stimulated } \\
\text { Inhibited }\end{array}$ & $0.96 \pm 0.01$ & & $0.90 \pm 0.01$ & & $0.93 \pm 0.01$ & \\
\hline $\begin{array}{l}\text { \% Abnormal } \\
\text { Totals } \\
\text { \% Abnormal } \\
\text { Controls }\end{array}$ & $\begin{array}{l}0 \\
0.89 \pm 0.13(32) \\
57 \\
0.99 \pm 0.04(12)\end{array}$ & $<0.005$ & $\begin{array}{l}0 \\
0.85 \\
58 \\
0.95 \\
0.0 .09(18)\end{array}$ & $<0.005$ & $\begin{array}{l}0 \\
0.88 \pm 0.19(36) \\
61 \\
0.97 \pm 0.07(12)\end{array}$ & $<0.005$ \\
\hline
\end{tabular}

Table I Migration indices (mean $\pm S D$ ) obtained with colon preparations in different categories of Crohn's patients with significance of difference (Mann-Whitney $U$ test) from control group 


\begin{tabular}{lll}
\hline Subject & $\begin{array}{l}\text { Rat Liver } \\
\text { Mitochondria }\end{array}$ & Colonic Mitochondria \\
\hline Controls & $0.89 \pm 0.19(18)$ & $0.95 \pm 0.09(12)$ \\
Crohn's patients & $0.89 \pm 0.17(10)$ & $0.80 \pm 0.10(29)$ \\
\hline
\end{tabular}

Table II Migration indices (mean $\pm S E$ ) obtained with colonic and rat liver mitochondria in Crohn's patients and normal subjects

by those patients in a clinically active phase of the disease and not on immunosuppressive treatment with prednisone or azathioprine.

In order to check that the mitochondrial reaction was organ specific, an additional series of tests was done using rat liver mitochondria standardized to $100 \mu \mathrm{g} / \mathrm{ml}$ protein content in the final culture medium. The results, shown in table II, demonstrate no significant difference in leucocyte migration against this antigen between the normal and Crohn's groups.

\section{Discussion}

The leucocyte migration test is now well established as a correlate of delayed hypersensitivity in vitro and has frequently been used to study cell-mediated immune mechanisms in a variety of diseases of suspected autoimmune origin, such as thyroiditis (Søborg and Halberg, 1968; Calder, McLeman, Barnes, and Irvine, 1972; Wartenberg, Doniach, Brostoff, and Roitt, 1973), idiopathic Addison's disease (Nerup, Andersen, and Bendixen, 1969), pernicious anaemia (Brostoff, 1970), and Crohn's disease (Willoughby and Mitchell, 1971; Brostoff and Walker, 1971; Richens et al, 1973). The results presented here indicate that a high proportion of patients in an active stage of Crohn's disease, not on immunosuppressive treatment, have circulating lymphocytes sensitized to constituents of the diseased colonic mucosa as shown by leucocyte migration inhibition. Another manifestation of this sensitization has recently been shown by the production of lymphotoxin cytotoxic to colonic epithelial cells by lymphocytes from patients with Crohn's disease of the colon and ulcerative colitis (Shorter, Huizenga, Spencer, and Guy, 1972). Attempts toidentify the components of the diseased colonic mucosa show that the crudehomogenate and both subcellular fractions are involved, with the mitochondrial fraction producing the most marked effect although this preparation of mitochondria was likely to have considerable microsomal contamination. Delayed hypersensitivity to mitochondria has been shown in other autoimmune diseases. It has been shown not to be organ specific in thyroid disease (Brostoff, 1970; Calder et al, 1972). However, the antigenic activity of mitochondria in Addison's disease has been reported as organ specific (Nerup et al, 1969). Our results appear to show that the effect is organ-specific as leucocytes from both Crohn's disease patients and healthy subjects showed no significant alteration of migration against rat liver mitochondria.

If in fact cell-mediated immune mechanisms play a part in the production of Crohn's lesions it is likely that the initial reaction is one involving a cellsurface component, the hypersensitivity to subcellular components posibly being a sequel to this event. However, in transplantation studies the spleen microsomal fractions have been found to be rich in transplantation antigen (Al-Askari and Lawrence, 1973) so that this may be a false assumption.

While the aetiology and pathogenesis of Crohn's disease and ulcerative colitis are unknown, further study of immune mechanisms in patients with these diseases should be of value. It has been shown that extracts of fetal, colonic, and jejunoileal mucosas inhibit migration of leucocytes from patients with ulcerative colitis, but not those with Crohn's disease (Bendixen, 1969). Our studies show migration inhibition of leucocytes from patients with Crohn's disease against Crohn's colon, and a further immunological differentiation between the two conditions would be apparent if further work showed that leucocytes from ulcerative colitis patients did not react in this way.

\section{References}

Al-Askari, S., and Lawrence, H. S. (1973). In vitro studies on transplantation immunity. II. Cell Immunol., 6, 292-299.

Bendixen, G. (1969). Cellular hypersensitivity to components of intestinal mucosa in ulcerative colitis and Crohn's disease. Gut, 10, 631-636.

Bendixen, G., and Søborg, M. (1969). A leucocyte migration technique for in vitro detection of cellular (delayed type) hypersensitivity in man. Dan. med. Bull., 16, 1-6.

Brostoff, J. (1970). Migration inhibition studies in human disease. Proc. roy. soc. Med., 63, 905-906.

Brostoff, J., and Walker, J. G. (1971). Leucocyte migration inhibition with Kvein antigen in Crohn's disease. Clin. exp. Immunol., 9, 707-711.

Calder, E. A., McLeman, D., Barnes, E. W., and Irvine, W. J. (1972). The effect of thyroid antigens on the in vitro migration of leucocytes from patients with Hashimoto thyroiditis. Clin. exp. Immunol., 12, 429-438.

Guillou, P. J., Brennan, T. G., and Giles, G. R. (1973). Lymphocyte transformation in the mesenteric lymph nodes of patients with Crohn's disease. Gut, 14, 20-24.

Lowry, O. H., Rosebrough, N. J., Farr, A. L., and Randall, R. J. (1951). Protein measurement with the Folin phenol reagent. J. biol. Chem., 193, 265-275.

Nerup, J., Andersen, V., and Bendixen, G. (1969). Anti-adrenal cellular hypersensitivity in Addison's disease. Clin. exp. Immunol., 4, 355-363.

Parent, K., Barrett, J., and Dodd Wilson, I. (1971). Investigation of the pathogenic mechanisms in regional enteritis with in vitro lymphocyte cultures. Gastroenterology, 61, 431-9. 
Phear, D. N. (1959). Relation between regional ileitis and sarcoidosis. Lancet, 2, 1250-1251.

Richens, E. R., Gough, K. R., and Williams, M, J. (1973). Leucocyte migration studies with spleen preparations in Crohn's disease. Gut, 14, 376-379.

Shorter, R. G., Huizenga, K. A., Spencer, R. J., and Guy, S. K. (1972). Inflammatory bowel disease: the role of lymphotoxin in the cytotoxicity of lymphocytes for colonic epithelial cells. Amer.J. dig. Dis., 17, 689-696.

Søborg, M. (1967). In vitro detection of cellular hypersensitivity in man. Specific migration inhibition of white blood cells from brucella-positive persons. Acta med. Scand., 182, 167-174.

Søborg, M., and Halberg, P. (1968). Cellular hypersensitivity in Hashimoto's thyroiditis Acta med. scand., 183, 101-105.

Wartenberg, J., Doniach, D., Brostoff, J., and Roitt, I. M. (1973). Leucocyte migration inhibition with mitochondria in human autoimmune-thyroid disorders. Clin. exp.Immunol., 14, 203-212. Willoughby, J. M. T., and Mitchell, D. N. (1971). In-vitro inhibition of leucocyte migration in Crohn's disease by a sarcoid spleen suspension. Brit. med. J., 2, 155-157.

\section{The December 1973 Issue}

\section{THE DECEMBER 1973 ISSUE CONTAINS THE FOLLOWING PAPERS}

A controlled therapeutic trial of long-term maintenance treatment of ulcerative colitis with sulphasalazine (Salazopyrin) $\quad$ A. S. DISSANAYAKE AND S. C. TRUELOVE

Liver biopsy and prognosis in acute liver failure J. SCOTTO, P. OPOLON, J. ÉtÉvÉ, D. VEGOZ, M. THOMAS, AND J. CAROLI

'Erythropoietic' protoporphyria and cirrhosis in sisters R. P. H. THOMPSON, E. A. MOLlAND, D. C. NICHOLSON, AND C. H. GRAY

Serum alpha-fetoprotein levels in acute viral hepatitis M. C. KEW, L. R. PURVES, AND I. BERSOHN

Piasma and urinary zinc in patients with malabsorption syndromes or hepatic cirrhosis B. E. WALKER, J. B. DAWSON, J. KELLEHER, AND M. S. LOSOWSKY

Increase of active transport of conjugated bile salts in streptozotocin-diabetic rat small intestine W. F. CASPARY

The effect of phenobarbital on cholesterol gallstones in hamsters

Changes in pancreatic morphology associated with aging LOUIS KREEL AND BRENDA SANDIN
Rectal and gastric involvement in a case of sarcoidosis S. R. GOULD, A. J. HANDLEY, AND D. E. BARNARDO

Effect of red chilli powder on DNA content of gastric aspirates H. G. DESAI, K. VENUGOPALAN, AND F. P. ANTIA

Solitary angiodysplastic lesions in the ileocaecal region diagnosed by angiography G. H. WHITEHOUSE

Effects of oral magnesium sulphate on colonic motility in patients with the irritable bowel syndrome R. F. HARVEY AND A. E. READ

Sieving characteristics of inflamed rectal mucosa J. RASK-MADSEN

\section{Progress report}

Colonoscopy CHRISTOPHER WILLIAMS AND ROBIN TEAGUE

Notes and activities

Index to Volume 14

Contents of Volume 14

Copies are still available and may be obtained from the PUBLISHING MANAGER, BRITISH MEDICAL ASSOCIATION, TAVISTOCK SQUARE, LONDON, WC1H 9JR, price $87 \frac{1}{2} \mathrm{p}$. 